\title{
Perceptions on voluntary adoption and certification of food safety management system HACCP: a case study of A\&B staff in a five-star hotel in Brazil
}

\author{
Percepções sobre adoção e certificação voluntária de sistema de gestão de segurança de alimentos \\ APPCC: um estudo de caso de equipe de A\&B em hotel cinco estrelas no Brasil \\ Percepciones sobre la adopción y certificación voluntaria del sistema de gestión de la seguridad \\ alimentaria HACCP: un estudio de caso del personal de A y B en un hotel de cinco estrellas en
}

Brasil

Received: 09/30/2021 | Reviewed: 10/09/2021 | Accept: 10/22/2021| Published: 10/23/2021

\author{
Janaina de Arruda Santos \\ ORCID: https://orcid.org/0000-0002-5457-6887 \\ Instituto Brasileiro de Medicina de Reabilitação, Brazil \\ E-mail: janainadeas@gmail.com \\ Simone Alves \\ ORCID: https://orcid.org/0000-0002-7582-0332 \\ Instituto Federal de Educação, Ciência e Tecnologia do Rio de Janeiro, Brazil \\ E-mail: simone.alves@ifrj.edu.br
}

\begin{abstract}
This study uses the in-depth case study method to evaluate the perceptions of managers and handlers of the Food and Beverage (A\&B) sector of a five-star hotel that has as a differential the certification by a Food Safety Management System (FSMS), based on Hazard Analysis and Critical Control Points (HACCP), for some of the products of its breakfast buffet. The data were collected through semi-structured interviews with 6 managers from the A\&B sector and a survey with their teams of food handlers $(\mathrm{N}=105)$, being later analyzed by Content Analysis, supported by Atlas.ti ${ }^{\mathrm{TM}}$ v.5.5 and descriptive statistics supported by SPSS $^{\mathrm{TM}}$ v. 14.0, respectively. The questionnaire used was previously tested, through consultation with experts and pre-test with a group of 20 food handlers from another hotel in the same hotel chain and with similar characteristics. The results obtained show considerable contrast in the socioeconomic classes and education of the employees of both groups, which may influence their overall perceptions of food safety. And, although both groups agree that an FSMS based on a voluntary and certified HACCP system can represent a competitive advantage for the hotel, most food handlers do not seem to perceive certified products differently in practice. Finally, the study points out the need to better communicate food safety certification in hotels in order to make it tangible, transferring added value to the business.
\end{abstract}

Keywords: Food safety culture; Hospitality; Food handlers; HACCP; Food and beverage.

\section{Resumo}

Este estudo utiliza o método do estudo de caso em profundidade para avaliar as percepções de gerentes e manipuladores do setor Alimentos e Bebidas (A\&B) de um hotel cinco estrelas que possui como diferencial a certificação por um Sistema de Gestão de Segurança de Alimentos (SGSA), baseado na Análise de Perigos e Pontos Críticos de Controle (APPCC), para alguns dos produtos de seu buffet de café da manhã. Os dados foram coletados por entrevistas semiestruturadas com 6 gestores do setor $A \& B$ e levantamento por questionário (survey) com suas equipes de manipuladores de alimentos $(\mathrm{N}=105)$, sendo posteriormente analisados por Análise de Conteúdo, com apoio do Atlas.ti ${ }^{\circledR}$ v. 5.5 e por estatística descritiva, com apoio do SPSS $^{\circledR}$ v. 14.0 , respectivamente. O questionário utilizado foi previamente testado, por meio de consulta a especialistas e pré-teste com um grupo de 20 manipuladores de alimentos de outro hotel da mesma rede hoteleira e com características similares. Os resultados obtidos mostram considerável contraste nas classes socioeconômicas e na educação formal dos funcionários dos dois grupos, o que pode influenciar suas percepções globais sobre a segurança de alimentos. E, embora ambos os grupos concordem que um SGSA baseado em um sistema APPCC voluntário e certificado pode representar uma vantagem competitiva para o hotel, a maioria dos manipuladores de alimentos não parece perceber os produtos certificados de forma diferenciada na prática. Por fim, aponta-se a necessidade de melhor comunicar a certificação de segurança de alimentos em hotelaria, de forma a torná-la tangível, transferindo valor agregado ao negócio.

Palavras-chave: Cultura de segurança de alimentos; Hospitalidade; Manipuladores de alimentos; APPCC; Alimentos e bebidas. 


\section{Resumen}

Este estudio utiliza el método de estudio de casos en profundidad para evaluar las percepciones de los gerentes y manipuladores del sector de Alimentos y Bebidas (A\&B) de un hotel de cinco estrellas que tiene como diferencial la certificación por un Sistema de Gestión de la Seguridad Alimentaria (SGSA), basado en el Análisis de Peligros y Puntos de Control Crítico (APPCC), para algunos de los productos de su buffet de desayuno. Los datos se recogieron mediante entrevistas semiestructuradas a 6 gerentes del sector A\&B y encuesta por cuestionario (Survey), con sus equipos de manipuladores de alimentos $(\mathrm{N}=105)$, siendo posteriormente analizados mediante Análisis de Contenido, apoyado por Atlas.ti ${ }^{\mathrm{TM}}$ v. 5.5 y estadística descriptiva apoyada por SPSS ${ }^{\mathrm{TM}}$ v. 14.0, respectivamente. El cuestionario utilizado se probó previamente, mediante la consulta a expertos y el ensayo previo con un grupo de 20 manipuladores de alimentos de otro hotel de la misma cadena hotelera y con características similares. Los resultados obtenidos muestran un considerable contraste en las clases socioeconómicas y la educación de los empleados de ambos grupos, lo que puede influir en sus percepciones generales de la seguridad alimentaria. Y, aunque ambos grupos están de acuerdo en que un SGF basado en un sistema APPCC voluntario y certificado puede representar una ventaja competitiva para el hotel, la mayoría de los manipuladores de alimentos no parecen percibir los productos certificados de forma diferente en la práctica. Por último, señalamos la necesidad de comunicar mejor la certificación de seguridad alimentaria en los hoteles para hacerla tangible, transfiriendo un valor añadido al negocio.

Palabras clave: Cultura de la seguridad alimentaria; Hospitalidade; Manipuladores de alimentos; APPCC; Alimentos y bebidas.

\section{Introduction}

Lodging is a providing of service, among which is highlighted that of food service under the responsibility of the area named Food \& Beverages (F\&B), which involves all food offered by hotels and all kind of lodging establishments, ranges from the breakfast buffets to meals served in their restaurants that also represent the haute cuisine of the city (Araújo, Gonçalves \& Mathias, 2014). These establishments offer food services for either guests who use their restaurants, bars and room services as well as for general customers who eat in their restaurants or in banquet services offered in social and corporate events held on their premises.

It is essential for the F\&B area on hospitality to pursue the continuous improvement of its products and processes, with the aim of providing food within hygienic sanitary criteria, in order to guarantee compliance with legal requirements, so that the customer might not be exposed to any type of potentially hazardous food resulting from improper processing (Saccol, Giacomelli, Mesquita, Castro, Silva Jr. \& Hecktheuer, 2015). In fact, it is believed that contaminated food is the leading cause of the so-called travel illnesses $(\mathrm{Wu}, 2012)$.

Food Safety Management System (FSMS) is a risk based method of controlling operational food safety hazards in businesses and the implementation of a Hazard Analysis and Critical Control Points (HACCP)-based FSMS is internationally seen as the most effective business intervention to protect the public from food borne disease (Abu Dhabi Food Control Authority [ADFCA], 2012). HACCP is a management tool that allows the prevention of physical, chemical, and biological hazards and consists of conducting a survey of hazards at each stage of production and listing control measures for each identified hazard, eliminating hazards or reducing them to an acceptable level (Rosseto, Batistella \& Veiga, 2020).

This kind of system is not yet a legal requirement in Brazil for food service, but some Brazilian establishments of this segment are becoming pioneers implementing a FSMS with additional controls not mandatory, such as those based on HACCP system. The initiative of including these additional controls aims to reduce risks on food safety as far as preventing the occurrence of Food-Borne Illnesses (FBI), in order to offer a market differential to the business and also aimed at improving customers' confidence in the establishment, fostering their loyalty (Tondo \& Bartz, 2014).

But for the efficiency of any FSMS it is important that all employees involved in the process, from senior management to operational staff, are aligned and sensitized to their importance, being aware of how to distinguish why and for what reasons perform their jobs, taking part in this stage of the supply chain that is established and in which they are involved (Taylor, Akanji, Al Shaikh, Collison, \& Whitehall, 2011; Baş, Yüksel \& Çavuşoğlu, 2005). 
The purpose of this study is to comparatively evaluate the perceptions of two groups in one food service staff, represented by F\&B managers and food handlers, of a Brazilian hotel that has adopted a pioneering FSMS model, which is certified by a HACCP-based system, which is a not a legal sanitary requirement in Brazil for food services. This hotel is rated as five-star tourist category and located in the city of Rio de Janeiro, one of main tourism destination of the country and where hospitality is considered one of the most relevant service sectors for the local economy.

\section{Material and Methods}

\subsection{Object of study}

The Hotel Group, in which the hotel unit under study is inserted, was founded in 1905 by a Brazilian entrepreneur. Up to 2017, this hotel chain managed 16 hotel units in Brazil and abroad, including its own hotels and franchises. The hotel unit selected for this study is located in Copacabana beach, in Rio de Janeiro city. It had 572 apartments distributed over 30 floors and counted with 462 employees, 136 of these (29.5\% of the total) allocated to the F\&B area and distributed into several departments, including nine management positions, at the time of the study was done.

The F\&B services of this hotel unit included breakfasts, lunches, dinners, suppers, sandwiches, snacks, coffee breaks, cocktails, room service, bars and event catering services in general, operating 24 hours per day according to the need of each type of service. The distribution of physical space related to F\&B area was generally made per place in which the goods are received and stored (dry and perishable food separately), as well as butchery, bakery and confectionery, central kitchen, restaurant kitchen, mess room, garbage storage, three restaurants and three bars.

The breakfast was the meal that accounts for the largest number of users in the hotel, serving approximately 650 people per day on average and reaching, during high season, volumes from 1,000 to 1,200 guests per day. The lunch was the second largest meal by volume of eaters, including meals (approximately 350) for the internal staff served in the mess room, with the other meals being served throughout the day in the hotel's restaurants (on average, 150 meals per day) and during events when contracted.

\subsection{Research strategy}

To achieve the objectives proposed in this study, the research strategy adopted was the Case Study (Yin, 2015) and, thus, the results obtained cannot be generalized. The preference for using the case study method in organizational research occurs in situations where behaviors cannot be manipulated, but it is possible to conduct direct on-site observations and systematic interviews, as in the case of this research.

This case study is of single, exploratory and in-depth type (Yin, 2015) and it uses both secondary and primary data collected through field research carried out in two complementary stages, starting by qualitative approach that served as the basis for a quantitative one. To better characterize and understand the specificities of the case, documentary research was carried out, improved by participant observation method (Mónico, Alferes, Castro \& Parreira, 2017).

The first research stage was carried out through in-depth semistructured interviews (Duarte, 2005) with six F\&B managers of the hotel, performed during August 2016. This period was strategically chosen because coincided with the Rio 2016 Olympic Games, a world mega-event that had a significant impact over the tourism in the Rio de Janeiro city, when it was observed an atypical increase of $116.1 \%$ on visitors in the city, compared to the same period in 2015 (Ministério do Turismo, 2017).

The second research stage was conducted in two steps: Pre-Test of proposed questionnaire and application of the revised/final version of questionnaire, by means of an exploratory and cross-sectional survey (Conelly, 2016), having a closedquestion questionnaire as data collection instrument, developed through literature review, with part of its questions evaluated 
by Likert scale (Garland, 1991; Patton, 1990).

The questionnaire was firstly pretested (Perneger, Courvoisier, Hudelson \& Gayet-Ageron, 2015) at June 2016 with a sample of twenty F\&B food handlers of a smaller hotel unit with the results further discussed with two specialists. This smaller hotel belongs to the same hotel Group and was also implementing a HACCP-based FSMS for its breakfast buffet at the time of the research, albeit to a lesser extent, since the size of its buffet was proportionally smaller than the one offered in the hotel studied. Nogueira (2002), as well as several other authors in the literature who discuss the methodology of survey research, recommends that for a correct and balanced questionnaire design, it should be pre-tested with individuals who might participate in the research, i.e., who have a similar profile to those who will participate in the research sample.

Finnaly, the reviewed version of the questionnaire, after the pre-test stage, was applied to a sample of 108 food handlers of the five-star hotel at study between May and June 2017.

. Both questionnaires, of pret-test stage and revised /final version, was applied by the researcher himself, who marked the answers of $\mathrm{F} \& \mathrm{~B}$ foof handlers on printed paper. The answers were later typed into the questionnaire that was hosted in the Survey Monkey research platform (https://pt.surveymonkey.com),

The questions of both versions of questionnaire were divided into seven blocks, similar as the division of five categories used in the script for the interviews with the F\&B managers in the first research stage. The first three blocks (I, II and III) were of simple closed questions and the four last blocks (IV, V, VI and VII), of a more subjective nature, were evaluated using Likert and were codified for further statistical analysis.

As there is no consensus in the literature regarding the most appropriate number of items for Likert scales, including whether even or odd (Dalmoro \& Vieira, 2013; Nogueira, 2002; Garland, 1991), the pre-test was also used to compare the results by adopting two alternative Lickert scale models: the traditional one with 5 points and a modified version, with 6 points. The pre-test results pointed the modified Likert scale model as the best option.

For analyzing the primary data collected in the qualitative research, it was adopted Content Analysis method (Mozzato \& Grzybovski, 2011) supported by Atlas.ti ${ }^{\mathrm{TM}}$ v.5.5 (Ronzani, da Costa, da Silva, Pigola \& de Paiva, 2020; Atlas.ti, $2009)$ and for those collected in the survey stage, it was adopted descriptive statistics to complete cases $(\mathrm{N}=105)$ analysis (Hair, Black, Babin \& Anderson, 2010), supported by SPSS ${ }^{\mathrm{TM}}$ v. 14.0 (SPSS Inc., 2005), using qualitative and quantitative methods combination (Jick, 1979). Content Analysis as a method of data analysis is widely applied in case studies that use interviews and traditionally works with written textual materials, such as those produced in research through the transcripts of interviews, which then refers to the empirical, experimental corpus (Caregnato \& Mutti, 2006). The use of software serves to assist the analysis and interpretation of the data, not excluding the participation of the researcher for the coherent and pertinent analysis to the theme (Mozzato \& Grzybovski, 2011).

Also, both groups in study, F\&B managers and food handlers, were classified into socio-economic classes according to the criteria proposed by the Brazilian Association of Research Companies (Associação Brasileira de Empresas de Pesquisa [ABEP], 2016).

\section{Results and Discussion}

\subsection{Literature Review}

The methodology for applying HACCP principles in economic sectors other than the large scale manufacturing has been the subject of research and development since last decade (ADFCA, 2012; Taylor, 2008; World Health Organization, \& Food and Agriculture Organization of the United Nations [WHO\&FAO], 2006). Also food safety management in food service, particularly in the hospitality F\&B area, has been a subject of growing interest to academics. Table 1 summarizes literature on 
the subject, from 2003 on, with emphasis on the researches carried out in Brazil.

Table 1. Food Safety Research in Hospitality review

\begin{tabular}{|c|c|c|c|c|}
\hline Authors (Year) & Study object & Stakeholders & Location & Main focus \\
\hline $\begin{array}{l}\text { Nascimento } \\
\text { (2003) }\end{array}$ & 10 Hotels & $\begin{array}{l}\text { Employees of the } 10 \\
\text { hotel kitchens }\end{array}$ & $\begin{array}{l}\text { Brasília-Distrito } \\
\text { Federal, } \\
\text { Brazil }\end{array}$ & $\begin{array}{l}\text { Existence of the GHP Manual, employees' } \\
\text { knowledge of food requirements and existence of } \\
\text { a nutritionist professional for coordinating quality } \\
\text { management system. }\end{array}$ \\
\hline $\begin{array}{c}\text { Röhr, Lüddecke, } \\
\text { Drusch, Müller } \\
\text { and Alvensleben } \\
\text { (2005) }\end{array}$ & 449 consumers & Residents of Kiel & Kiel, Germany & $\begin{array}{l}\text { Investigate the perception of food quality (in } \\
\text { terms of purchase criteria), perception of food } \\
\text { safety and health risks, attitudes belonging to food } \\
\text { safety and attitudes towards communicators of } \\
\text { food safety. }\end{array}$ \\
\hline $\begin{array}{l}\text { Moysés and } \\
\text { Moori (2006) }\end{array}$ & Hotel & $\begin{array}{l}7 \mathrm{~F} \& \mathrm{~B} \text { managers and } \\
50 \text { hotel guests }\end{array}$ & $\begin{array}{l}\text { Vale do Paraíba } \\
\text { region, São Paulo } \\
\text { State, Brazil }\end{array}$ & $\begin{array}{l}\text { Attributes of hotel (e.g. food safety system, } \\
\text { comfort, etc) most valued according to the } \\
\text { perception of guests and hotel managers. }\end{array}$ \\
\hline $\begin{array}{l}\text { Baş, Yüksel and } \\
\text { Çavuşoğlu, } \\
\text { (2007) }\end{array}$ & $\begin{array}{l}115 \text { food } \\
\text { businesses } \\
\text { responsible for } \\
109 \text { deals }\end{array}$ & $\begin{array}{l}\text { Hospital food } \\
\text { services (10), catering } \\
(22) \text {, hotels (11), } \\
\text { kebab houses (21), } \\
\text { takeaways (32) and } \\
\text { restaurants (19) }\end{array}$ & Ankara, Turkey & $\begin{array}{l}\text { Barriers for HACCP and FSMS in food } \\
\text { businesses. }\end{array}$ \\
\hline $\begin{array}{c}\text { Fletcher, } \\
\text { Maharaj and } \\
\text { James (2009) }\end{array}$ & 16 Hotels & $\begin{array}{l}\text { F\&B managers and } \\
\text { food handlers }\end{array}$ & $\begin{array}{l}\text { St. Mary e St. Anna, } \\
\text { Jamaica }\end{array}$ & $\begin{array}{l}\text { Existence of FSMS and perceptions of these two } \\
\text { groups about their relationship with the HACCP } \\
\text { and the commitment, motivation and challenges } \\
\text { levels in using it. }\end{array}$ \\
\hline $\begin{array}{l}\text { Almeida, Costa } \\
\text { and Gaspar } \\
\text { (2010) }\end{array}$ & Restaurant & $\begin{array}{l}\text { F\&B managers and } \\
\text { food handlers }\end{array}$ & $\begin{array}{l}\text { Rio de Janeiro-Rio } \\
\text { de Janeiro State, } \\
\text { Brazil }\end{array}$ & $\begin{array}{l}\text { Identification of shortcomings and suggestion of } \\
\text { simple, low-cost, day-to-day actions that could } \\
\text { bring effective improvements to routines for a } \\
\text { FSMS }\end{array}$ \\
\hline $\begin{array}{l}\text { Silva }(2010, \\
\text { 2012) }\end{array}$ & 13 Hotels & 13 hotels kitchens & $\begin{array}{l}\text { Caruaru- } \\
\text { Pernambuco State, } \\
\text { Brazil }\end{array}$ & $\begin{array}{l}\text { Check list application for evaluation of GHP, } \\
\text { GHP Manual and SOPs }\end{array}$ \\
\hline $\begin{array}{l}\text { Almeida and } \\
\text { Hostins (2011) }\end{array}$ & Seaside kioks & 405 Tourists & $\begin{array}{c}\text { Balneário } \\
\text { Camboriú-Santa } \\
\text { Catarina States, } \\
\text { Brazil }\end{array}$ & $\begin{array}{l}\text { Sanitary and hygienic conditions and the food } \\
\text { behavior of the tourists that consume these foods. }\end{array}$ \\
\hline $\begin{array}{l}\text { Castro, Barbosa } \\
\text { and Tabai (2011) }\end{array}$ & $\begin{array}{l}9 \text { shopping } \\
\text { centers' } \\
\text { restaurants }\end{array}$ & 109 food handlers & $\begin{array}{l}\text { Rio de Janeiro-Rio } \\
\text { de Janeiro State, } \\
\text { Brazil }\end{array}$ & The perception of food handlers about safe food. \\
\hline $\begin{array}{c}\text { Aguiar and } \\
\text { Carvalho (2012) }\end{array}$ & 4 hotels and inns & 97 tourists & $\begin{array}{c}\text { São Raimundo } \\
\text { Nonato-Piauí State, } \\
\text { Brazil } \\
\end{array}$ & $\begin{array}{l}\text { Tourist's profiles and satisfaction degree about } \\
\text { local food services. }\end{array}$ \\
\hline Wu (2013) & Hotel & $\begin{array}{l}7 \mathrm{~F} \& \mathrm{~B} \text { managers and } \\
\text { food handlers }\end{array}$ & Taiwan, China & FSMS implementation strategies \\
\hline Belém (2013) & 3 Hotels & hotel kitchens & $\begin{array}{l}\text { Brasília-Distrito } \\
\text { Federal, } \\
\text { Brazil } \\
\end{array}$ & $\begin{array}{l}\text { GHP evaluation, GHP Manual and SOPs } \\
\text { existence/implementation }\end{array}$ \\
\hline $\begin{array}{l}\text { Arendt, Paez and } \\
\text { Strohbehn (2013) }\end{array}$ & $\begin{array}{l}\text { Commercial and } \\
\text { non-commercial } \\
\text { food services }\end{array}$ & $\begin{array}{l}4 \text { focus group ( } 5 \text { to } 12 \\
\mathrm{~F} \& \mathrm{~B} \text { managers each) }\end{array}$ & Costa Rica & $\begin{array}{l}\text { Check managers' perspectives on their role and } \\
\text { the reasons for the unsafe food handling practices } \\
\text { of employees }\end{array}$ \\
\hline $\begin{array}{l}\text { Mayra, Silva, } \\
\text { Bezerra, Bezerra, } \\
\text { Santos,Souza, de }\end{array}$ & 2 Hotels & hotel kitchens & $\begin{array}{l}\text { Caruaru- } \\
\text { Pernambuco State, } \\
\text { Brazil }\end{array}$ & $\begin{array}{l}\text { GHP evaluation (items related to food handlers } \\
\text { such as hygiene and food handling) }\end{array}$ \\
\hline
\end{tabular}




\begin{tabular}{|c|c|c|c|c|}
\hline $\begin{array}{c}\text { Lima and } \\
\text { Fernandes (2014) }\end{array}$ & & & & \\
\hline $\begin{array}{c}\text { Bernardo, } \\
\text { Valentim, } \\
\text { Oliveira and } \\
\text { Ramos (2014) }\end{array}$ & 10 Hotels & hotel kitchens & $\begin{array}{c}\text { Belo Horizonte- } \\
\text { Minas Gerais State, } \\
\text { Brazil }\end{array}$ & $\begin{array}{l}\text { GHP evaluation, GHP Manual and SOPs } \\
\text { existence/implementation }\end{array}$ \\
\hline Andrade (2014) & 19 hotels and inns & $\begin{array}{l}19 \text { F\&B Managers and } \\
108 \text { food handlers }\end{array}$ & $\begin{array}{c}\text { São Paulo-São } \\
\text { Paulo State } \\
\text { Brazil } \\
\end{array}$ & $\begin{array}{l}\text { Food handlers and F\&B managers perceptions } \\
\text { over the food safety }\end{array}$ \\
\hline $\begin{array}{c}\text { Gomes, Lemos, } \\
\text { Silva, Hora and } \\
\text { Cruz (2014) }\end{array}$ & Hotel & Food handlers & $\begin{array}{c}\text { Rio de Janeiro- Rio } \\
\text { de Janeiro State, } \\
\text { Brazil }\end{array}$ & Food handlers training on GHP \\
\hline $\begin{array}{c}\text { Lopes, Silveira, } \\
\text { and Floriano } \\
(2015)\end{array}$ & 10 Hotels & hotel kitchens & $\begin{array}{c}\text { Uruguaiana-Rio } \\
\text { Grande do Sul } \\
\text { State, Brazil }\end{array}$ & GHP evaluation, and food handlers' health \\
\hline $\begin{array}{c}\text { Jeinie, Sharif, } \\
\text { Saad and Nor } \\
(2016)\end{array}$ & Hotel & $\begin{array}{l}5 \text { students of culinary } \\
\text { art in hotel restaurant }\end{array}$ & Selangor, Malaysia & $\begin{array}{l}\text { FSMS effectiveness of personal/environmental } \\
\text { hygienic practices }\end{array}$ \\
\hline $\begin{array}{c}\text { Binz, Theodoro } \\
\text { and Bernardi } \\
\text { (2019) }\end{array}$ & 06 Hotels & hotel kitchens & $\begin{array}{c}\text { Gramado-Rio } \\
\text { Grande do Sul } \\
\text { State, } \\
\text { Brazil }\end{array}$ & $\begin{array}{l}\text { Relationship between hotel size, food hygienic } \\
\text { and sanitary quality; GHP }\end{array}$ \\
\hline
\end{tabular}

Legend: GHP = Good Hygiene Practices; SOPs = Standard Operation Procedures

Source: own study.

\subsection{The Food Safety Management System}

In 2010, the GHP was implemented in the F\&B throughout the hotel chain. And in pursuing excellence in the Quality Assurance System of the sector, the hotel unit under study adopted an HACCP-based system to control the items of greater consumption of its breakfast buffet, the only meal included in the lodging service. This system was certified in September 2014 by Bureau Veritas as HACCP System-Codex Alimentarius and includes seven product groups with a total of twenty food preparations: scrambled eggs, oatmeal porridge, frankfurters in tomato Sauce, portioned fruits (specifically papaya, pineapple, honey dew melon, cantaloupe, watermelon, mango and kiwi), fruit salad, five types of cheese (gouda, tilsit, minas frescal, minas light and prato) and four types of sausages (turkey blanquet, processed ham, smoked ham and salami). In next year 2015, a follow-up audit was carried out and five additional food preparations were also included in this control system (bacon, roasted Italian sausage, cooked bananas, sautéed potatoes and grilled tomatoes), totaling 25 products certified according to Codex Alimentarius (2003) Standards.

These certified food preparations received individualized HACCP plans, developed by F\&B team according to the methodology suggested by Tondo and Bartz (2014), containing the description of all production stages, from the receipt to distribution, respective controls adopted and specific criteria for each product group, which are sometimes more stringent and beyond Good Hygiene Practices (GHP) requirements.

The HACCP plans began with a purpose description, which it is the assessment of the hazards and risks involved in the specific preparation and the implementation of control measures that guarantee the innocuousness of the preparation. These documents also contained company identification, names and respective roles of all HACCP team members involved and described the adopted criteria for assessing hazards and risks associated with each preparation or food group. The identified hazards were also assessed for their severity and probability of occurrence, being classified by their respective risks. In the context of food safety, risk means the function of the probability of occurrence of an adverse health effect and the severity of this effect, when there is exposure to a specific hazard. While severity, is considered a measure of hazard seriousness, that is, the consequence of it (Tondo \& Bartz, 2014). 
After performing the risk classification for each preparation step certified by the HACCP-based system, the methodology adopted by the hotel established which steps were considered relevant to be treated as Critical Control Points (CCP), as well as the corresponding execution record. Also the microbiological criteria acceptable in the final product were then verified according to the current sanitary legislation - in the case of Brazil, the Resolution Nr. 12/2001 (known as RDC Nr. 12) of the National Health Surveillance Agency (Agência Nacional de Vigilância Sanitária [ANVISA], 2001) -, in accordance with the characteristics of each preparation.

The HACCP plans also describe, in addition to the type of preparation, which allergenic substances may be present, the characteristics of the final product and its form of distribution (including conservation temperatures), its shelf-life and special controls to be adopted during the its distribution. The preparation flowchart was also part of HACCP plans developed and it had included, in addition to the descriptions of all stages and ingredients used in the preparation, the signaling of the stages in which there was Control Points (CP) and Critical Control Points (CCP) and the respective quality criteria adopted.

A chart was then prepared with hazard analysis, which also described each ingredient used in the preparation and its steps in the flowchart, classifying hazards as physical, chemical or biological, category of severity, probability, risk and respective control measures adopted. Finally, the Decision Tree (also known as Decision Diagram) was used to identify CCP according to the Codex Alimentarius (2003) criteria.

In order to conclude the HACCP plan, aSummary was prepared, describing only the identified CP and CCP as wells its hazard, control measure, critical limit (with the reason or reference for its adoption) and monitoring process (and how it was carried out) established. Also, it was included on this summary, the respective corrective action (in case of non-compliance or result beyond critical limit), and how monitoring process verifications and records should be done, being the associated worksheets attached at the end of each HACCP plan.

\subsection{Qualitative research}

The group of interviewees was composed of three men and three women who held management positions in the hotel's F\&B area, corresponding to $67 \%$ of the total of nine managers who make up the team and its respective roles, at August 2016 (see Table 2).

Table 2. Profile of F\&B managers interviewed

\begin{tabular}{c|c|c|c|c|c}
\hline F\&B manager role & Age & Gender & Education & $\begin{array}{c}\text { Experience in } \\
\text { hospitality } \\
\text { (years) }\end{array}$ & $\begin{array}{c}\text { Experience in } \\
\text { this hotel } \\
\text { (years) }\end{array}$ \\
\hline Head of steward & 59 & Male & High school & 38 & 24 \\
\hline Chef & 64 & Male & Graduate & 49 & 9 \\
\hline Food safety coordinator & 31 & Female & Postgraduate & 5 & 2 \\
\hline F\&B manager & 25 & Female & Graduate & 2 & 1 \\
\hline Restaurant supervisor & 30 & Male & Graduate & 10 & 2 \\
\hline
\end{tabular}

Source: own study.

The age range of the interviewees varied between 25 and 64 years of age. Four of them have completed graduate or postgraduate courses related to F\&B (as nutrition, gastronomy and hospitality areas) and the others have completed high school. Three of the interviewees have previous experience in hospitality F\&B and all the interviewees have been working for more than a year in this hotel - the senior one has worked for 38 years in hospitality, 24 years of them in the hotel. 
The interviews were recorded and the audio was transcribed to be analyzed by Content Analysis (Mozzato \& Grzybovski, 2011) with Atlas.ti ${ }^{\mathrm{TM}}$ software v. 5.5 (Atlas.ti, 2009). So, the transcribed content was classified into five categories for content analysis and comparison purposes: (i) Personal view on FSQMS; (ii) Food Safety Culture at the hotel; (iii) Food handlers' personal hygiene; (iv) Risk perceptions; and (v) Influence of managers on food safety.

The results show that the interviewed managers deem the voluntary FSMS implementation in this hotel unit as relevant, particularly, the HACCP-based system applied to its breakfast buffet. According these managers the main challenges and motivations related to one FSMS' implementation and maintenance was refered to the development of an own food safety culture and employees' care with their personal hygiene, as well as improvement in the F\&B team risk perception on hazards related to FBI, especially in food handlers.

These F\&B managers also understood that it is an essential role of organization to ensure continuous training and support to food handlers on food safety, since the practice of healthy habits plays a fundamental role in the personal responsibility of providing safe and quality food to the guests. They also believed that their own attitudes directly influence the behavior of their teams, considering themselves as integral parts of the successful implementation of any quality management system, including those related to the $F \& B$, mentioning the importance of the manager's behavior when in the kitchens and in other food handling areas as example.

It was also noted that, although this F\&B managers group was concerned with preventing the occurrence of foodborne outbreaks, most of them considered this risk to be low in their work environment. Additionally, all interviewed managers considered that the adoption of the voluntary HACCP-based system positively affected the image of the hotel and confered upon the organization and higher status regarding the quality of its services as a whole to guests, even though this system has been deployed only for a specific group of breakfast buffet products. Among the main benefits highlighted by the managers as being a motivation for implementing a voluntary AHCCP system were: better prevention of FBI, achievement of competitive advantages to the organization and improvement of the quality of food served to the guests.

In relation to the Olympic Games RIO 2016 period, there were divergent opinions among the interviewees. Two of the managers declared that believed that the risk associated with food-borne outbreaks does not increased along with the hotel's increased occupancy rate, showing to be confidents about the daily food quality controls already carried out at the hotel. In turn, the majority of them (the other four managers) were not sure about the issue, considering that could have an increase in risk in this circumstance and that the hotel food safety controls should be intensified on these occasions, in order to prevent possible incidents caused by increased food handling inherent to increased tourist traffic.

Finally, despite their personal perceptions that the hotel's image was improved with the HACCP certification achieved for part of its breakfast buffet products, almost all of them (five of the interviewees) believed that there was still no appropriate publicity by the organization side to transform those achievement into a competitive advantage for this specific hotel or for its hotel Group as a whole, which could influence the choice of accommodation of tourists and F\&B customers by this hotel and by all its hotel chain as consequence. A more detailed analysis of these results, obtained at this first research stage, was published by Santos, Alves and Hora (2018a).

The results are also aligned with previous studies on food safety perceptions. One example is the study carried out in Malaysian restaurants of hotels by Jeinie et al. (2016), who interviewed employees related to food handling. The results obtained by these authors indicate that all interviewees demonstrated a positive perception of FSMS implementation in food services, agreeing that its deployment is important so that safe food can be offered in their workplace.

Also Arendt, Paez and Strohbehn (2013), in a research with actual and future F\&B managers in Costa Rica's hospitality, found that one of the main challenges for implementing a FSMS, according to the opinion of the interviewees, was the difficulty overcoming the resistance of the employees to food safety practices. The study points out that one of the reasons 
for this resistance is that those employees disbelief that the safe food handling procedures must be really complied with, as well as traditionally low salaries of this category can also be a demotivating factor for food handlers.

A similar scenario was found in the present study with F\&B managers interviewed, who reported that many of the food handlers in the hotel studied do not have yet developed their own food safety culture and do not see any importance in the required hygiene practices, leading some of them to adopt these practice only as an obligation. The interviewed managers also believed that one of the greatest difficulties faced in this hotel kitchen was the lack of recognition by the food handlers themselves that they can be vehicles for FBI. And also observed by Arendt, Paez and Strohbehn (2013), these managers recognized their role of responsibility for the application of food safety rules. So, in both studies, F\&B managers reported that they are responsible for monitoring the behavior of the food handlers and for demonstrating to them that food safety procedures are important for the organization.

Interviewees to Arendt et al. (2013) study revealed that their immediate concern as managers was to comply with the company's emerging and daily contractual commitments, and also stating that the supply of safe food depends not only on the quality management system adopted to ensure food safety, but also on other factors that influence it, such as company culture, managers' understanding of food safety and a vision for continuous improvement, knowledge of process management, adoption of food quality prerequisite programs, structured treatment of non-conformities, leadership and cost and overhead planning. These interviewees also believed that food safety concepts must be associated with the company's and employees' cultures so that the FSMS adopted may work efficiently.

The managers interviewed by Arendt et al. (2013) believed that, for the implementation of the HACCP-based system, it was essential that employees who work directly in food production be convinced that, by systematically controlling the production stages indicated as critical control points, there will be a decrease in the risk of food contamination (Almeida, Costa \& Gaspar, 2010). This belief was also observed in this present case study, which interviewed F\&B managers also expressed the belief that, for the supply of safe food, a food safety culture must also be created by the part of its food handlers.

Oliveira Júnior et al. (2021) pointed up that employees who work with food safety are potential tools in the transmission of foodborne illnesses and therefore must be trained, in their study these authors found that employees must undergo periodic training, all of which being recorded. The authors even emphasize the importance of adopting the proper methodology for this.

\subsection{Quantitative research}

The questions of porposed questionnaire were divided into seven blocks, similar as the division of five categories used in the script for the interviews with the F\&B managers in the first qualitative research stage. The first three blocks (I, II and III) are of simple closed questions and the four last blocks (IV, V, VI and VII), of a more subjective nature, were evaluated using a 6-point Likert modified scale and were codified for further statistical analysis. The summary of the seven blocks and the respective number of questions of each one are illustrated at Table 3. 
Table 3. Questionnaire questions

\begin{tabular}{|c|c|c|c|c|}
\hline \multirow{2}{*}{ Block } & Description & \multicolumn{2}{c|}{ Questions } & \multirow{2}{*}{ Codification } \\
\cline { 3 - 4 } I & Profile of the respondent (food handler) & 8 & $\begin{array}{c}\text { simple/closed } \\
\text { questions }\end{array}$ & \multirow{2}{*}{ N.A. $^{(1)}$} \\
\hline II & Classification by socio-economic class & 15 & $\begin{array}{c}\text { Simple/closed } \\
\text { questions }\end{array}$ & N.A. $^{(1)}$ \\
\hline III & Access to basic sanitation in their residence & 3 & $\begin{array}{c}\text { Simple/closed } \\
\text { questions }\end{array}$ & N.A. $^{(1)}$ \\
\hline IV & $\begin{array}{c}\text { Personal view (PV) on FSMS (particularly on the } \\
\text { HACCP-based system certification for this hotel } \\
\text { breakfast buffet products) }\end{array}$ & 3 & Lickert scale & PV \\
\hline V & Personal food safety culture / hygiene habits & 3 & Lickert scale & FSC \\
\hline VI & Personal perception of risk to food safety & 3 & Lickert scale & PR \\
\hline VII & $\begin{array}{c}\text { Influence of managers on food safety practice in } \\
\text { the hotel }\end{array}$ & 2 & Lickert scale & INF \\
\hline
\end{tabular}

Notes: N.A. - Not Applicable

Source: own study.

A total of 108 respondents took part on this research, selected by non-probability sampling and by convenience. But only complete cases were considered for analysis $(\mathrm{N}=105)$. Figure 1 illustrates the profile of those F\&B food handlers.

Figure 1. Profile of the F\&B food handlers respondents

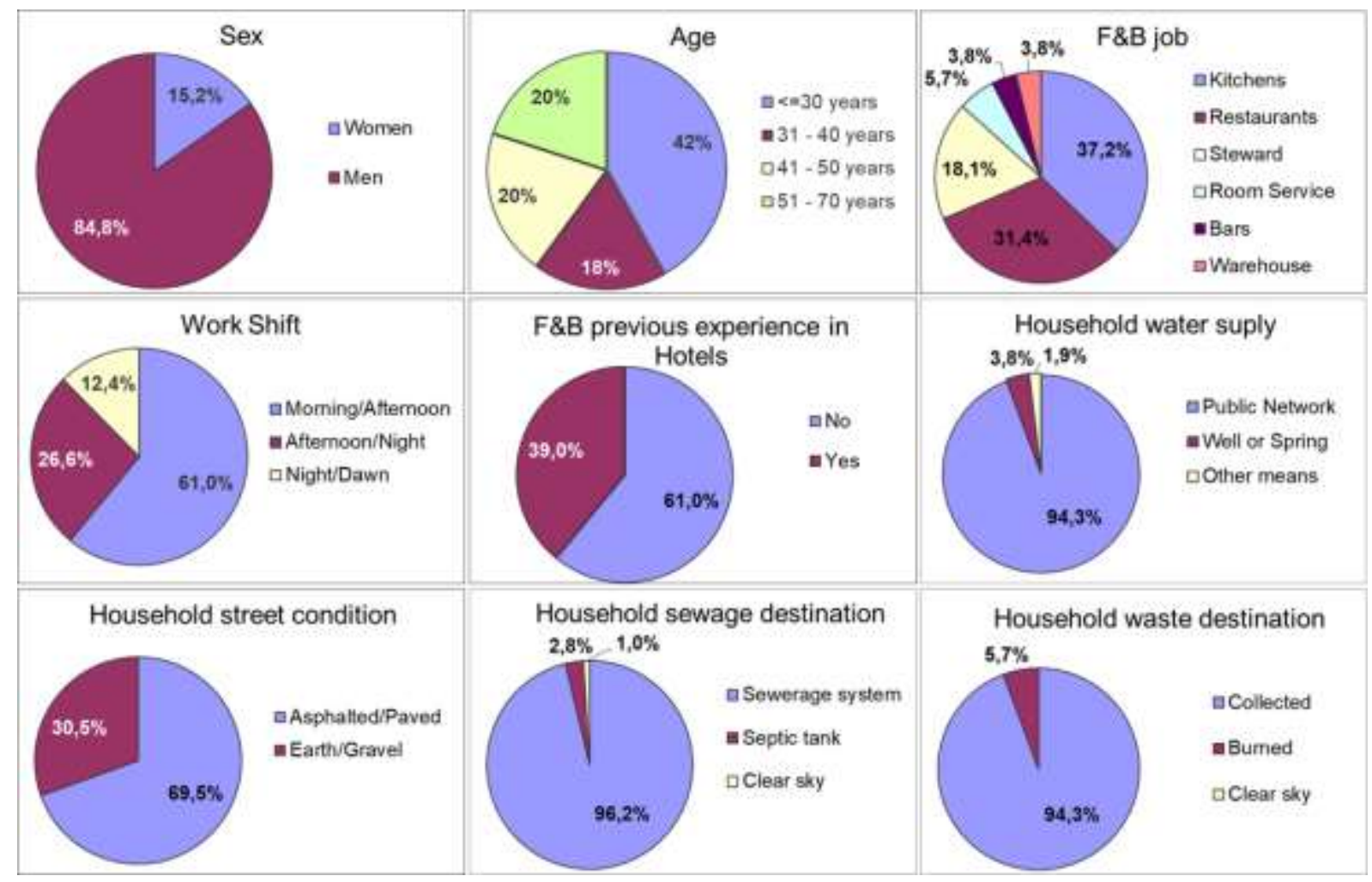

Source: own study.

The data were processed using the SPSS ${ }^{\mathrm{TM}}$ v.15.0 (SPSS inc., 2005) for descriptive analysis and resulting statistics are summarized in Table 4. 
Table 4. Descriptive statistics for the survey with F\&B food handlers.

\begin{tabular}{|c|c|c|c|c|c|}
\hline $\begin{array}{c}\text { Variable / Question } \\
\text { Codification }\end{array}$ & $\begin{array}{c}\text { Questionnaire } \\
\text { question }\end{array}$ & Average & $\begin{array}{l}\text { Standard } \\
\text { deviation }\end{array}$ & $\begin{array}{c}\text { Minimum }_{\text {value }^{(3)}} \\
\text { Mand }\end{array}$ & $\begin{array}{c}\text { Maximum }_{\text {value }^{(3)}} \\
\text { Mand }\end{array}$ \\
\hline Age & I. 5 & $\begin{array}{l}36,7 \\
\text { years }\end{array}$ & 13,5 & 19 years & 69 years \\
\hline Socio-economic class & $\begin{array}{l}\text { I.7, II.1 a II.11, } \\
\text { II.13 e II.15 }\end{array}$ & 3,1 & 0,9 & N.A. ${ }^{(1)}$ & N.A. ${ }^{(1)}$ \\
\hline \multicolumn{6}{|c|}{ PV - Personal View on the FSMS } \\
\hline Question 1 (PV1) & IV.1 & 1,7 & 0,6 & 1 & 4 \\
\hline Question 2 (PV2) & IV.2 & 1,9 & 0,9 & 1 & 5 \\
\hline Question 3 (PV3) & IV. 3 & 3,2 & 1,2 & 1 & 6 \\
\hline \multicolumn{6}{|c|}{ FSC - Food Safety Culture } \\
\hline Question 1 (FSC1) & V.1 & 1,8 & 0,7 & 1 & 4 \\
\hline Question 2 (FSC2) & V.2 & 2,3 & 0,8 & 1 & 5 \\
\hline Question 3 (FSC3) & V.3 & 3,5 & 1,5 & 1 & 6 \\
\hline \multicolumn{6}{|c|}{ PR - Perceptions of risk to food safety } \\
\hline Question 1 (PR1) & VI.1 & 3,0 & 1,0 & 1 & 6 \\
\hline Question 2 (PR2) & VI.2 & 2,8 & 1,0 & 1 & 6 \\
\hline Question 3 (PR3) & VI.3 & 4,0 & 1,5 & 1 & 6 \\
\hline \multicolumn{6}{|c|}{ INF - Influence of managers on food safety practice } \\
\hline Question 1 (INF1) & VII.1 & 3,6 & 1,6 & 1 & 6 \\
\hline Question 2 INF2 & VII.2 & 2,6 & 1,2 & 1 & 6 \\
\hline
\end{tabular}

Notes:

1) N.A. - Not Applicable;

2) Minimum/ Maximum values from 1 to 6 refer to the 6-point Lickert scale adopted, whose answers were evaluated from Totally Agree $=1$ to Totally Disagree $=6$.

Source: own study.

The results obtained at this second stage of the research were discussed separately at a previous publication of Santos, Alves and Hora (2018b), but not compared with the obtained results for F\&B managers interviewed group, at first stage of this research.Figure 2 shows a first kind of this comparison, highlighting the diferences in socio-economic classes for the two $\mathrm{F} \& \mathrm{~B}$ groups (managers and food handlers). The classification follows criteria proposed by the Brazilian Association of Research Companies (ABEP, 2016).

Figure 2. Comparison of the socio-economic classes for the two F\&B groups.

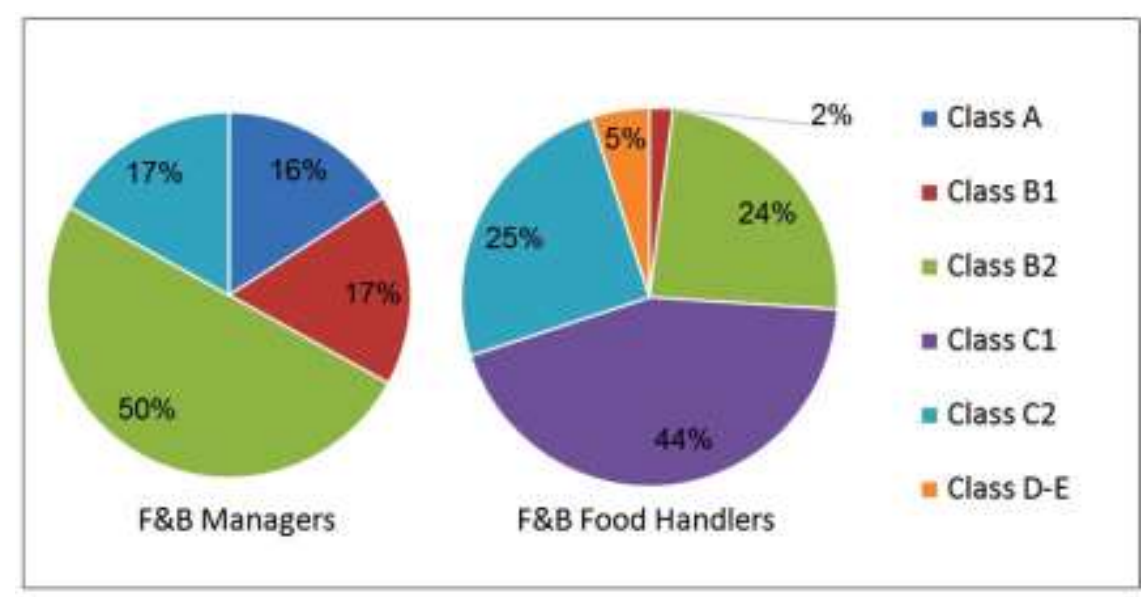

Source: own study. 
These results point a considerable difference in the profiles of the two groups as can be observed in Figure 2 and as it was already observed in previous similar researches (Aguiar \& Kraemer, 2010).

It is important to stress that the two surveyed groups in the present study agreed on the need for the hotel to seek disclosure to the public (guests, investors and potential customers) of the achieved HACCP certification, so that this achievement could indeed become a competitive advantage for the hotel, and the desired market differential could become a reality and not just a desire.

The visibility of the difference in quality controls for the HACCP certified items was not a point equally emphasized by both the managers and the food handlers. F\&B managers pointed out that they believed that unsatisfactory environment and personal dissatisfaction or personal problems of the employees could affect their performance. But this hypothesis was not confirmed by food handlers' opinions about themselves. In fact, considering the responses of the food handlers to this subject, most of them do not agreed that their dissatisfaction and sorrows directly affect the performance of their professional activities.

With respect to the food safety culture, it was also observed contradictory results related to food handlers behavior at home and the importance they attribute to food safety procedures at the hotel, indicating that, even considering that proper hygiene practices are important, not all of them are followed outside the work environment, beyond the performance of professional activities. This point also is consistent with the uncertainty demonstrated by the F\&B managers regarding the practices of the employees who integrate their teams, since despite agreeing that the food handlers followed the rules because they are part of their duty, some of them still believe that this can happen only to part of their team. Unanimously, the F\&B managers mentioned that they believed that only part of their team has a consolidated food safety culture. These managers also believed that their employees clearly understand whether the procedures are right or wrong according GHP, but most apply them only as an obligation. This perception was confirmed by the high degree of agreement among food handlers when considering that the training received at the hotel were able to change their own hygiene habits, however, contrasting with the finding that, despite this change, they still use at home practices that are not favorable to food safety, revealing the conflict of information and positioning regarding their reality.

The F\&B managers agreed that, in addition to the culture brought from home, hygienic habits and sanitary conditions of the food handlers in their homes could be a determining factor for the conduct of employees in kitchens and sectors involving food and drinks in the hotel, once again confirming that the creation of a food safety culture is necessary to raise awareness of the correct and safe procedures as already discussed by Yannas (2014).

Although, according to the results of the survey, it was verified that the housing conditions of most of the food handlers included in the sample do not revealed precarious data, with more than $90 \%$ of them having access to water supply service, sewage and urban waste disposal, provided by public distribution, revealing adequate housing conditions regarding basic sanitation. Only the condition of the stretch of street got a slightly lower percentage in relation to the mentioned services $(69.5 \%)$ for asphalt or paved condition. So, all these results tend to collaborate in forming good hygiene habits in food handlers also in the hotel.

Personal hygiene and, above all, hand hygiene were valued by both, the interviewed F\&B managers and food handlers. Both of them demonstrated the appreciation of personal hygiene as a factor that contributes to the prevention of outbreaks and that hand hygiene is the most important procedure in kitchens.

With regard to the impact of the greater tourism flow on food safety controls, associated with the period of the 2016 Olympic Games in the city of Rio de Janeiro, two of the managers interviewed demonstrated that they did not consider the risk of food-borne outbreaks as being increased. On the other hand, the remaining managers reported being insecure at the time, as there was no special operation adopted by the hotel for this period. They believed that procedures to ensure food safety should have been intensified due to increased tourist traffic. Most food handlers, however, did not agree with most of the management 
team, showing uncertainty as to the absence of a strategy to reinforce their usual food control, which, in their opinion, exposed guests to an increased risk of food-borne outbreaks.

According the influence of the management's knowledge on GHP, the two groups researched, F\&B managers and food handlers, acknowledge that senior F\&B positions should be opinion leaders, always being a role model for the F\&B team by demonstrating their knowledge on food safety standards and its execution in the hotel. The food handlers revealed that, if the F\&B management shows uncertainty regard these procedures and their own knowledge on the subject, this consequently could induce failures to all the team.

Regarding the valuation of HACCP-based system certification by F\&B managers and food handlers, all F\&B managers agreed that it is important to keep this kind of FSMS coupled with a GHP solid basis, and that this system adopted by the hotel for some food preparation of its breakfast buffet is a positive point for the hotel and its hotelier chain, as well as a very appropriate food quality additional control. On the other hand, although the food handlers demonstrated that they conceptually value this control system - they also recommended for the hotel to publicly exhibit the HACCP-based FSMS certificate to the guests, as a way of valuing the hotel food service -, this group seem to be unable to perceive, in the practice, the difference between the certified and non-certified food served and its safety and quality. This dichotomy in the food handlers' perception towards the HACCP-based FSMS certification, between the theoretical view expressed in the certificate itself and the practical view of differentiation between certified and non-certified food, means certainly a failure in the process of FSMS implementation and a challenge to search for optimizing food handlers' motivation and improving F\&B team training in order to promote the so important internalization of principles of this FSMS model pioneered by the hotel.

\section{Conclusion}

The purpose of this study is to comparatively evaluate the perceptions of two groups in one food service team, represented by F\&B managers and food handlers of a Brazilian hotel that has adopted a pioneering FSMS model, which is certified by a HACCP-based system, which is a not a legal sanitary requirement in Brazil for food services. This hotel is rated as five-star tourist category and located in the city of Rio de Janeiro, one of main tourism destination of the country. For this, in-depth interviews with six F\&B managers and a survey with their team of food handlers $(\mathrm{N}=105)$ were used as methodology whose data were analyzed by Content Analysis method and descriptive statistics.

The results of this study indicate that - as expected due to different salary levels and education profiles of each group - there is a considerable difference in the socio-economic classes of F\&B managers and food handlers under their management. This difference may not only influence their own perceptions towards issues related to food safety and to the FSMS HACCP-based system, but also the formation of a personal and collective food safety culture, in each of these two groups and in the hotel as a whole.

It is recommended that such a difference, that is expected not to be exclusive to this hotel but a characteristic of food service teams, must be considered by F\&B managers when designing GHP and FSMS trainings and during day-to-day supervision and practical guidance of their team. It is also suggested that the reality of life mappings of these food handlers team (such as the analysis of their socio-economic classes, for example, as made in this study) could be developed and may be used to better understand the probable personal limitations of the employees under the responsibility of F\&B managers. In the same way, it was verified through the results of this study that the difference of schooling between the two groups (F\&B managers and food handlers) may be an additional challenge for a better understanding between both groups regarding appropriate F\&B procedures, including food safety standards.

The implementation of FSMS HACCP-based system is a stimulus to the development of a food safety culture in the food services business and, more specifically, for the hospitality industry, which combines food and gastronomy. The direct 
comparison with the food industry experience on this subject, does not directly apply to this segment, due to the number of preparations and variability of products served in those places. But it is expected that, as already observed in food industry, the construction of a more solid scientific base on the subject may give subsidies to the application in food services not only of this differentiated quality control and food safety systems, but also to help food services to move towards even more secure and complex food control systems, such as ISO 22000, adding even greater value to the services provided to their customers.

At the same time, it is expected that the administrative and operational efforts required to certify and maintain these FSMS model in the hospitality industry could begin to be strategically and explicitly communicated to the public and, above all, to the hotel guests, so that the hospitality companies can actually count on this as a competitive advantage over the increasingly fierce competition in this economic sector.

It is expected that this work will be a contribution and stimulus for the implementation and maintenance of systems related to food safety, including HACCP, in hotels and that its benefits could be perceived by the teams involved in the direct and indirect handling of food, bringing value added to the final consumer and raising the level of organizations with regard to the provision of safe food.

It is also suggested that future studies applied to this area of knowledge be carried out in order to broaden the scientific base on the subject, and that such studies seek to deepen the subsequent steps of the HACCP system, such as the implementation of stricter certification standards, like ISO 22000.

Other suggestions of continuity for the present study would be to deepen aspects not included in the applied questionnaire and already tested in other data collection instruments in similar studies, such as those proposed by Cunha, Braga, Passos, Stedefeldtd and Rosso (2015) for the evaluation of the optimism bias and by Matukuma (2021) for the evaluation of aspects related to food safety culture.

Finally, an important point to note is that the study was conducted in a different scenario of the actual one, before the world was hit by the Covid-19 pandemic. This experience most likely changed the general perception about the importance of hand hygiene and surfaces as a health safety measures, including the F\&B professionals themselves who act as food handlers. It is important that future studies verify this hypothesis, because this probable greater appreciation of the measures already adopted in the GMP criteria, and also the method of controlling operational food safety hazards in businesses and the implementation of a Hazard Analysis and Critical Control Points (HACCP)-based FSMS in food service area such as the one studied, could have become credentials even more valued by tourists and guests.

\section{References}

Abu Dhabi Food Control Authority. (2012). A guide to the preparation of a HACCP-based food safety management system for hotels. Code of practice No. 18. https://www.adfca.ae/English/PolicyAndLegislations/Guidelines/Documents/Hotels\%2018.pdf

Agência Nacional de Vigilância Sanitária (2001). "Resolução da Diretoria Colegiada - RDC n 12", Ministério da Saúde. Brasília, DF, Brasil. http://portal.anvisa.gov.br/documents/33880/2568070/RDC_12_2001.pdf/15ffddf6-3767-4527-bfac-740a0400829b

Aguiar, E. P. S., \& Carvalho, S. M. S. (2012). Turistas de São Raimundo Nonato - PI: Perfil e grau de satisfação quanto aos serviços de alimentação. Turismo em Análise, 23(3), 600-622.

Aguiar, O. B. D., \& Kraemer, F. B. (2010). Educação formal, informal e não-formal na qualificação profissional dos trabalhadores de alimentação coletiva. Nutrire - Revista da Sociedade. Brasileira de Alimentação e Nutrição, 35 (3), 87-96.

Almeida, E. B., \& Hostins, R. C. L. (2011). O comportamento alimentar do turista e sua segurança no consumo de milho verde e churros à beira-mar. Turismo: Visão e Ação, 13(3), 347-361.

Almeida, G. L., Costa, S. R. R., \& Gaspar, A. (2010). A questão da gestão da segurança de alimentos em restaurantes comerciais do tipo self-service: O estudo de um caso. Gestão da Produção, Operações e Sistemas, 5(2), 11-26.

Andrade, M. L. (2014). Segurança dos alimentos no setor hoteleiro: caracterização das empresas e avaliação da percepção dos agentes envolvidos - estudo de caso. São Paulo, SP, Brazil: Dissertação de Mestrado, Universidade de São Paulo. http://www6.ensp.fiocruz.br/visa/files/Marcel_Levy_de_Andrade.pdf 
Araújo, R. M., Gonçalves, S., \& Matias, I. (2014). Hospitalidade comercial nos serviços de restauração: Uma análise em Mossoró/RN. Revista de Cultura e Turismo, 8(1), 59-94.

Arendt, S. W., Paez, P., \& Strohbehn, C. (2013). Food safety practices and managers' perceptions: A qualitative study in hospitality. International Journal of Contemporary Hospitality Management, 25(1), 124-139.

Associação Brasileira de Empresas de Pesquisa (2016). Critério Brasil 2015 e atualização da distribuição de classes para 2016. http://www.abep.org/Servicos/Download.aspx?id=12

Atlas.ti. (2009). ATLAS.ti Scientific Software Development GmbH. Qualitative Data Analysis, version 5.5. Berlin.

Baş, M., Yüksel, M., \& Çavuşoğlu, T. (2007). Difficulties and barriers for the implementing of HACCP and food safety systems in food businesses in Turkey. Food Control, 18(2), 124-130.

Belém, J. C. (2013). Estudo preliminar sobre o diagnóstico situacional em relação às Boas Práticas no setor de Alimentos e Bebidas de hotéis localizados no setor hoteleiro Norte e Sul de Brasília, DF. Brasília, DF, Brazil. Trabalho de Conclusão de Curso, Universidade de Brasília; http://bdm.unb.br/bitstream/10483/6309/1/2013_JaquelineCintraBelem.pdf

Bernardo, P. V., Valentim, E. C. N., Oliveira, A. E. S., \& Ramos, S. A. (2014). Good practices in the production of meals in hotels of Belo Horizonte, MG. UNOPAR Científica Ciências Biológicas e da Saúde, 16(4), 265-270.

Binz, P., Theodoro, H., \& Bernardi, J. R. (2019). Qualidade higiênico-sanitária na produção de refeições em hotéis segundo o porte. In Ciência e Tecnologia dos Alimentos (Vol. 2, pp.119 - 126). Belo Horizonte,MG: Poison.

Caregnato, R. C. A, \& Mutti, R. (2006) Pesquisa Qualitativa: análise de discurso versus análise de conteúdo. Texto Contexto Enfermagem, Florianópolis, 15(4), 679-684.

Castro, F. T., Barbosa, C. G., \& Tabai, K. C. (2011). Perfil dos manipuladores de alimentos e a ótica desses profissionais sobre alimento seguro no Rio de Janeiro (RJ). Oikos: Família e Sociedade em Debate, 22(1), 153-170.

Codex Alimentarius. (2003). Código Internacional Recomendado de Práticas - Princípios Gerais de Higiene dos Alimentos. Versão Portuguesa. CAC/RCP 11969 Rev. 4, FAO/WHO. http://www.actionlive.pt/docs/actionalimentar/codex_alimentarius_VersaoPortuguesa_2003.pdf

Conelly, L. M. (2016, Sep/Oct). Cross-sectional survey research. MedSurg Nursing, 25 (5), 369-370.

Cunha D. M., Braga, A. R. C., Passos, E. C., Stedefeldtd, E., \& Rosso, V. V. (2015, Sep.). The existence of optimistic bias about foodborne disease by food handlers and its association with training participation and food safety performance. Food Research International. 75, 27-33.

Dalmoro, M; \& Vieira, K. M. (2013) Dilemas na construção de escalas tipo Likert: o número de itens e a disposição influenciam nos resultados? Revista Gestão Organizacional, Edição Especial Epistemologia e Métodos de Pesquisa em Administração e Contabilidade, 6(3), 161-174.

Duarte, J. (2005). Entrevista em profundidade. Métodos e técnicas de pesquisa em comunicação. São Paulo: Atlas, 1, 62-83.

Fletcher, S. M., Maharaj, S. R., \& James, K. (2009). Description of the food safety system in hotels and how it compares with HACCP standards. Journal of Travel Medicine, 16(1), 35-41.

Garland, R. (1991). The Mid-Point on a Rating Scale: Is it Desirable? Marketing Bulletin, Research Note 3, 66-70.

Gomes, C. C. B., Lemos, G. F. C., Silva, M. C, Hora, I. M. C. \& Cruz, A. G. (2014). Training of food handlers in a hotel: Tool for promotion of the food safety. Journal of Food Safety, 34(3), 218-223.

Hair, J. F., Black, W.C., Babin, B. J., \& Anderson, R. E. (2010) Multivariate Data Analysis. 7th Edition, Pearson, New York.

Jeinie, M. H., Sharif, M. S. M, Saad, M. \& Nor, N. M. (2016, abril). Food safety and hygiene practice among hotel in Malaysia: Qualitative approach. Anais do 7th Asian Conference on Environment-Behaviour Studies. National Taiwan University, Taipei, Taiwan.

Jick, T. D. (1979). Mixing qualitative and quantitative methods: Triangulation in action. Administrative science quarterly, 24(4), 602-611.

Oliveira Júnior, G. M. de, Lima Segundo, J. F. de, \& Jerônimo, H. M. A.. (2021). Assessment of the level of learning from handlers on good food handling practices. Research, Society and Development, 10(1), e36310111796.

Lopes, L. L., Silveira, J. T., \& Floriano, J. M. (2015). Condições higiênico-sanitárias de serviços de alimentação em hotéis de Uruguaiana, Rio Grande do Sul. Nutrivisa - Revista de Nutrição e Vigilância em Saúde, 2(1), 16-21.

Matukuma, C. A. (2021). Refinamento e aplicação de instrumento de caracterização de Cultura de Segurança de Alimentos. Dissertação de Mestrado, Faculdade de Medicina Veterinária e Zootecnia, Universidade de São Paulo, São Paulo. https://www.teses.usp.br/teses/disponiveis/10/10134/tde-07052021115203/publico/Cristiane_Aparecida_Matukuma_original.pdf

Mayara, N., Silva, M. G., Bezerra, M. J., Bezerra, M. Q., Santos, F. M., Souza, E. A., \& de Lima Fernandes, M. A. (2015). Condições higiênico sanitárias das unidades produtoras de alimentos em hotéis do município de Caruaru, Pernambuco. Veredas: Revista Eletrônica de Ciências, 7(2), 109-122.

Ministério do Turismo. (2017). Anuário Estatístico de Turismo - 2016. http://www.dadosefatos.turismo.gov.br/2016-02-04-11-53-05.html 
Mónico, L., Alferes, V., Parreira, P., \& Castro, P. A. (2017). A Observação Participante enquanto metodologia de investigação qualitativa. In António Pedro Costa, Simone Tuzzo, Catarina Brandão (Eds.). 6º. Congresso Ibero-americano de Investigação Qualitativa (CIAIQ2017). Atas - Investigação Qualitativa em Ciências Sociais, 3. https://proceedings.ciaiq.org/index.php/ciaiq2017/article/view/1447

Moysés, G. L. R. \& Moori, R. G. (2006, outubro). A qualidade em serviços e a gestão da capacidade: um estudo das percepções do hóspede e do gestor do hotel. Anais do XXVI Encontro Nacional de Engenharia de Produção, Fortaleza, CE, Brazil, 26.

Mozzato, A. R., \& Grzybovski, D. (2011). Análise de conteúdo como técnica de análise de dados qualitativos no campo da administração: Potencial e desafios. RAC. Revista de Administração Contemporânea, 15(4), 731-747.

Nascimento, L. B. (2003). Aplicação das Boas Práticas de Fabricação no preparo de refeições como garantia de qualidade do produto final oferecido aos hóspedes nos hotéis dos setores hoteleiros norte e sul da cidade de Brasília. Brasília, DF, Brazil. Monografia de Especialização, Universidade de Brasília; http://bdm.unb.br/bitstream/10483/252/1/2003_LucileneBentesNascimento.pdf

Nogueira, R. (2002) Elaboração e análise de questionários: uma revisão da literatura básica e a aplicação dos conceitos a um caso real. Instituto Coppead de Administração, Universidade Federal do Rio de Janeiro. Relatórios Coppead, n. 350. COPPEAD, UFRJ: Rio de Janeiro.

Patton, M. (1990). Qualitative evaluation and research methods. Beverly Hills, CA: Sage.

Perneger, T. V., Courvoisier, D. S., Hudelson, P. M., \& Gayet-Ageron, A. (2015). Sample size for pre-tests of questionnaires. Quality of Life Research, 24(1), $147-151$.

Ronzani, C. M., da Costa, P. R., da Silva, L. F., Pigola, A., \& de Paiva, E. M. (2020). Qualitative methods of analysis: an example of Atlas. TI'm Software usage. Revista Gestão \& Tecnologia, 20(4), 284-311.

Röhr, A., Lüddecke, K., Drusch, S., Müller, M. J., \& Alvensleben, R. B. (2005). Food quality and safety - consumer perception and public health concern. Food Control, 16(8), 649-655.

Rosseto, M., Batistella, V. M. C., \& Veiga, R. L. (2020). Análise de perigos e pontos críticos de controle: Um estudo de caso em uma propriedade leiteira do Município de Sertão, Rio Grande do Sul, Brasil. Research, Society and Development, 9(8), e69985136.

Saccol, A. L. F., Giacomelli, S. C., Mesquita, M. O., Castro, A. K. F., Silva Jr., E. A., \& Hecktheuer, L. H. R. (2015). Sanitary legislation governing food services in Brazil. Food Control, 52, 27-33.

Santos, J. A., Alves, S., \& Hora, I. M. C. (2018a) Sistemas de segurança de alimentos em serviços de alimentação: Um estudo de caso com gestores de A\&B em um hotel 5 estrelas no Rio de Janeiro. In Joice Lavandoski, Adriana Brambilla and Elidio Vanzella (Eds.). Alimentação e Turismo: oferta e segmentos turísticos. Série Alimentação e Cultura. João Pessoa: Editora do Centro de Comunicação, Cultura e Artes, Universidade Federal da Paraíba, $279-305$.

Santos, J. A., Alves, S., \& Hora, I. M. C. (2018b). Manipuladores de alimentos: O que pensa o elo mais frágil da cadeia de alimentação no turismo sobre Sistemas de Gestão da Segurança de Alimentos. In Joice Lavandoski, Adriana Brambilla and Elidio Vanzella (Eds.). Alimentação e Turismo: oferta e segmentos turísticos. Série Alimentação e Cultura. João Pessoa: Editora do Centro de Comunicação, Cultura e Artes, Universidade Federal da Paraíba, $185-216$.

Silva, G. P. (2012). Avaliação das boas práticas em unidades produtoras de refeição dos hotéis do município de Caruaru-PE. Higiene Alimentar, 26(214), 40-44.

Silva, G. P. (2010). Avaliação das boas práticas em unidades produtoras de refeição dos hotéis do município de Caruaru-PE. Monografia de Bacharelado, Faculdade do Vale do Ipojuca. Caruaru, PE, Brazil: FAVIP; http://repositorio.favip.edu.br:8080/bitstream/ 123456789/1200/1/AVALIA\%C3\%87\%C3\%83O+DAS+BOAS+PR\%C3\%81TICAS+EM+UNIDADES+PRODUTORAS+DE+REFEI\%C3\%87.pdf

SPSS Inc. SPSS for windows, version 14.0 [Computer Program]. Chicago: SPSS Inc; 2005.

Taylor, E. (2008). HACCP for the hospitality industry: history in the making. International Journal of Contemporary Hospitality Management, $20(5), 480-493$.

Taylor, J., Akanji, T., Al Shaikh, A., Collison, F., \& Whitehall, P. (2011). Barriers to HACCP in hospitality: A global problem with global solutions? Worldwide Hospitality and Tourism Themes, 3(5), 387-401.

Tondo, E. C., \& Bartz, S. (2014). Microbiologia e sistemas de gestão da segurança de alimentos. Porto Alegre: Sulina.

World Health Organization, \& Food and Agriculture Organization of the United Nations (2006). FAO/WHO guidance to governments on the application of HACCP in small and/or less-developed food businesses. FAO food and nutrition paper, 86, 1-74.

Wu, S. (2013). Innovative food safety strategies in a pioneering hotel. Food and Nutrition Sciences, 4(10), 1054-1059.

Wu, S. (2012). Factors influencing the implementation of food safety control systems in Taiwanese international tourist hotels. Food Control, $28(2), 265-272$.

Yannas, F. (2014) Cultura de segurança de alimentos: criando um sistema de gestão de segurança de alimentos baseado em comportamento. (Ellen Lopes, trad.). São Paulo: Food Design.

Yin, R. K. (2015) Estudo de caso: planejamento e métodos. 5 ed., Porto Alegre: Bookman. 